\title{
Opium and Cigarette Smoking are Independently Associated with Bladder Cancer: The Findings of a Matched Case - Control Study
}

\author{
Zahra Abdolahinia ${ }^{1}$, Hamid Pakmanesh ${ }^{2}$, Moghaddameh Mirzaee ${ }^{3}$, Azam \\ Bazrafshan $^{4}$, Mehdi Shafiei Bafti ${ }^{5}$, Armita Shahesmaeili ${ }^{1 *}$
}

\begin{abstract}
Background: Bladder cancer disproportionally affects the communities. While it is the ninth most common cancer in the world, in some parts of Iran including Kerman province it is the most common cancer among men. This study aimed to determine potential risk factors of bladder cancer in Kerman province, Iran. Methods: During February to July 2020, in this matched hospital-based case-control study, 100 patients with bladder cancer and 200 healthy individuals (matched in age and sex) were recruited. Socio-demographics status, occupational exposures, common diet, history of drug use and family history of cancer, were collected using a structured questionnaire. Bivariable and multivariable logistic regression were applied and crude and adjusted odds ratios (AOR) along with their 95\% confidence intervals (95\%CI) were calculated. Data were analyzed using Stata version 14 software. Results: Opium consumption, cigarette smoking and low level of income were associated with increased chance of bladder cancer. Compared to never use, use of opium up to 18000 Gram -year was associated with increased chance of bladder cancer (AOR: 6; 95\% CI $=2.3$, 15.5). The chance was higher among those who used opium more than $18,000 \mathrm{Gram}$ - year (AOR: $11.3 ; 95 \% \mathrm{CI}=2.3$, 15.5). In comparison with never smokers, the chance of bladder cancer increased among those who smoked up to 20 pack-year cigarette) (AOR: $3.4 ; 95 \% \mathrm{CI}=1.3,8.9)$ and those who smoke $\geq 20$ pack-year (AOR: $15.8 ; 95 \% \mathrm{CI}=5.9$, 42.4).Conclusions: The observed strong dose-response association between opium consumption, cigarette smoking and bladder cancer highlights the need for extension of harm reduction programs especially in regions with high burden of disease.
\end{abstract}

Keywords: Opioid- Cigarette smoking- bladder neoplasm- Iran- Kerman

Asian Pac J Cancer Prev, 22 (10), 3385-3391

\section{Introduction}

Bladder cancer is the ninth most common cancer globally, affecting more than 430,000 men and imposing a high social and economic burden on individuals and health care systems globally (Khazaei et al., 2019), especially among men and the elderly (Miller et al., 2018). In 2018, it was estimated that approximately $3 \%$ of all newly diagnosed cancers and $2.1 \%$ of all cancer-related deaths globally were due to bladder cancer (Khazaei et al., 2019).

In Iran, bladder cancer is showing an increasing trend (Hassanipour et al., 2019), with more than 70,000 new cases and 30,000 registered deaths annually (Ahmadi et al., 2012). It is the fifth most common cancer among Iranian men (Farmanfarma et al., 2020). However, there are some variations in the incidence of bladder cancer between geographical areas. Kerman, a province located in southeast Iran, with an age-standardized incidence rate (ASR) of 24.6 per 100,000 population - compared to the ASR of 10.9 for the whole country (Hassanipour et al., 2019) - is one of the areas where bladder cancer is most prevalent (Shahesmaeili et al., 2018). Disparities in environmental, contextual, and individual factors may explain the high incidence of bladder cancer in Kerman. However, the studies on assessing underlying factors are scarce.

A variety of factors, including behavioral, environmental, and occupational risk factors, have been associated with the increased risk of this cancer. Tobacco use, opium consumption, some occupational exposures

${ }^{1}$ HIV/STI Surveillance Research Center, and WHO Collaborating center for HIV surveillance, Institute for Futures Studies in Health, Kerman University of Medical Sciences, Kerman, Iran. ${ }^{2}$ Department of Urology, Faculty of Medicine, Kerman University of Medical Sciences, Kerman, Iran. ${ }^{3}$ Modeling in Health Research Center, Institute for Futures Studies in Health, Kerman University of Medical Sciences, Kerman, Iran. ${ }^{4}$ Kerman Population-based Cancer Registry (KPBCR), Deputy of Health, Kerman University of Medical Sciences, Kerman, Iran. ${ }^{5}$ Department of Communicable Diseases, Kerman University of Medical Sciences, Kerman, Iran.*For Correspondence: a.shahesmaeili@kmu.ac.ir 
such as exposure to aromatic amines and black carbon, which are produced in painting, the plastics industry, and coal mines, positive family history, diet, and prolonged consumption of water contaminated with arsenic or chlorine are among the main risk factors (Koutros et al., 2016; Bravi et al., 2018; Wong et al., 2018).

Kerman province is one of the provinces richest in mineral resources in the country, and the city of Kerman is surrounded by a variety of active mines, including copper, coal, iron, and titanium mines (Najafipour et al., 2015). Furthermore, the latest studies in Kerman province indicate that the mean concentration of groundwater heavy metals such as arsenic in some districts is higher than the standard value (Malakootian and Mohammadi Senjedkooh, 2014; Nazari and Abbasnejad, 2015). Additionally, the prevalence of opium consumption, a known risk factor of bladder cancer, in Kerman province is higher than the national average (21\%) (Shahesmaeili et al., 2018).

Therefore, there is a wide range of possible risk factors in Kerman, explaining the higher rate of bladder cancer in this province. However, there is no comprehensive study in which the role of all possible risk factors and the potential interaction between them are studied simultaneously. As determining the principal risk factors and high-risk groups may be beneficial to the prevention, screening and early diagnosis of this disease, this matched case-control study aimed to identify the risk factors of bladder cancer in Kerman province.

\section{Materials and Methods}

\section{Study design and participants}

In this matched hospital-based case-control study, 100 cases and 200 controls who were aged above 40 and had consented to participate in the study were recruited from February to July 2020. Cases were patients with confirmed bladder cancer who referred to the urology department of Bahonar Hospital, a teaching hospital affiliated with Kerman University of Medical Sciences, for treatment workup. For each case, we selected two controls: one from patients referred to the ophthalmology department of Shafa general hospital, Kerman, Iran, and another from patients referred to the urology department of Bahonar Hospital, Kerman, Iran, who had undergone cystoscopy due to diseases unrelated to the bladder; the absence of bladder tumors in controls selected from the urology department was confirmed by cystoscopy. The controls had no history of cancer, and cases and controls were matched based on age ( \pm 5 years) and sex.

\section{Study instrument:}

Data were collected through face-to-face interviews using a structured questionnaire. The questionnaire consisted of 50 questions categorized into five sections: socio-demographics, occupational exposure, common diet, history of drug use (cigarettes, opium, hookah, and alcohol), and family history of cancer.

\section{Independent variables}

Pack years smoked was calculated using the following formula: pack-year $=$ (number of cigarettes smoked per day $\div 20$ cigarettes) $\mathrm{x}$ number of years. Three groups were defined according to the pack-year: never smokers, light smokers (up to 20 pack-years), and heavy smokers ( $\geq 20$ pack-years). Similarly, the amount of opium consumption was calculated based on gram-years and categorized into two groups: $<18,000$ gram-years and $\geq 18,000$ gram-years in lifetime. Other potential risk factors measured were: monthly income ( $<20$ vs. $\geq 20$ million rials), education ( $<12$ vs. $\geq 12$ years), use of alcohol (never vs. ever used), exposure to second-hand smoke (yes vs. no), age of smoking onset ( $<20 \mathrm{vs}$. $\geq 20$ years), age of first opium use ( $<25$ vs. $\geq 25$ years), second hand exposure to opium (yes vs. no), use of hookah (yes vs. no), use of opium derivatives (yes vs. no), history of work in industrial factories (yes vs. no), history of work as a driver (yes vs. no), history of work as a farmer (yes vs. no), history of work as a construction worker (yes vs. no), residing in proximity to industrial zone $(<2 \mathrm{~km} \mathrm{vs}$. $\geq 2 \mathrm{~km}$ ), exposure to chemical fertilizers (yes vs. no), use of grilled foods ( $<1$ time vs. $1-3$ times vs. $\geq 4$ times per week), use of stuck-pot ( $<1$ time vs. $1-3$ times vs. $\geq 4$ times per week), use of carbonated drinks and juices with preservatives $(<1$ time vs. $1-3$ times vs. $\geq 4$ times per week), use of eggs $(<$ 1 time vs. $1-3$ times vs. $\geq 4$ times per week), cereal (1-3 times vs. $\geq 4$ times per week), and pickles ( $<1$ time vs. $1-3$ times vs. $\geq 4$ times per week).

\section{Statistical analysis}

Data were analyzed using Stata version 14. To explore factors associated with bladder cancer, we applied bivariate and multivariable logistic regression, and crude and adjusted odds ratios (AORs) along with their 95\% confidence intervals $(95 \% \mathrm{CI})$ were reported. Variables with a $\mathrm{P}$-value $<0.2$ in the bivariate analysis were entered into the multivariable regression model. The final model was reduced based on the F-test, and P-values $<0.05$ were considered statistically significant.

\section{Ethics}

The study protocol was reviewed and approved by the Research Review Board of the Kerman University of Medical Sciences (ethics code: IR.KMU.REC.1398.603). The risks and benefits of the study were explained to all eligible participants to obtain verbal informed consent; each potential participant had the choice to accept or refuse to participate in the study. All interviews were conducted anonymously in a private setting.

\section{Results}

\section{Characteristics of study participants}

In the present study, 300 participants (100 cases and 200 hospital controls) were recruited. Most participants were male $(85.9 \%$ in cases, $83 \%$ in controls), educated less than 12 years $(82.8 \%$ in cases, $70 \%$ in controls), earned less than 20 million rials $(80.8 \%$ in cases, $62.5 \%$ in controls), and were married (89.9\% in cases, $88 \%$ in controls). The mean ages of the cases and controls were $63.6 \pm 9.65$ and $59.3 \pm 11$ years, respectively (Table 1).

Overall, $71.7 \%$ of cases and $17 \%$ of controls had a 
Table 1. Socio-Demographic Characteristics of 100 Cases with Bladder Cancer and 200 Hospital-Based Controls, in Kerman Province in 2020

\begin{tabular}{|c|c|c|c|}
\hline variables & $\begin{array}{c}\text { Case } \\
(\mathrm{n}=100) \\
\mathrm{N}(\%)\end{array}$ & $\begin{array}{c}\text { Control } \\
(\mathrm{n}=200) \\
\mathrm{N}(\%)\end{array}$ & p-value \\
\hline Sex & & & 0.52 \\
\hline Female & $14(14.4)$ & $34(17)$ & \\
\hline Male & $85(85.9)$ & $166(83)$ & \\
\hline Age at interview & & & 0.11 \\
\hline $40-65$ & $56(56.6)$ & $132(66)$ & \\
\hline$\geq 65$ & $43(43.4)$ & $68(34)$ & \\
\hline Education (years) & & & 0.01 \\
\hline$<12$ & $82(82.8)$ & $140(70)$ & \\
\hline$\geq 12$ & $17(17.2)$ & $60(30)$ & \\
\hline Income & & & 0.001 \\
\hline$<20$ million Rials & $80(80.8)$ & $125(62.5)$ & \\
\hline$\geq 20$ million Rials & $19(19.2)$ & $75(37.5)$ & \\
\hline Marital status & & & 0.70 \\
\hline Single & $10(10.1)$ & $24(12)$ & \\
\hline Married & $89(89.9)$ & $176(88)$ & \\
\hline
\end{tabular}

history of cigarette smoking, and around $74.8 \%$ of cases and $14.5 \%$ of controls had used opium. In the majority of participants, the age at onset of cigarette smoking was $\geq 20$ years (77.5\% in cases vs. $79.4 \%$ in controls), and most participants had started opium use $\geq 25$ years $(73 \%$ in cases vs. $75 \%$ in controls). The distribution of other drugs used is summarized in Table 2.

\section{Bladder-cancer-associated factors}

Compared to controls, cases were less likely to be educated $\geq 12$ years $(\% 17.2$ vs. $30 \%, P=0.01)$, and earned $\geq 20$ million rials $(19.2 \%$ vs. $37.5 \%, P=0.001)$. They were more likely to smoke $\geq 20$ pack-years Cigarette in their life time $(52.5 \%$ vs. $5 \%, \mathrm{P}<0.001)$, use $\geq 18,000$ gram years opium in their lifetime $(50.6 \%$ vs. $7.5 \%, \mathrm{P}<$ $0.001)$, use alcohol $(8.2 \%$ vs. $2 \%, P=0.02)$, be exposed to second-hand smoke ( $40.4 \%$ vs. $27 \%, \mathrm{P}=0.02)$, have a history of working in a factory $(10.1 \%$ vs. $4 \%, \mathrm{P}=0.03)$, reside near an industrial zone $(18.2 \%$ vs. $9 \%, \mathrm{P}=0.03)$, be exposed to chemical fertilizers $(41.4 \%$ vs. $27.5 \%$, $\mathrm{P}=0.01)$, have a history of working as driver $(23.2 \%$ vs. $7 \%, \mathrm{P}<0.001)$, have a history of working as farmer (56.6\% vs. $43.5 \%, \mathrm{P}=0.03)$, have a history of working as a construction worker $(22.2 \%$ vs. $8 \%, \mathrm{P}=0.001)$, use grilled food 4-6 times per week ( $6.6 \%$ vs. $5.1 \%, \mathrm{P}=0.02)$, use carbonated drinks and juices with preservatives 4-6 times per week ( $47.5 \%$ vs. $33.3 \%, \mathrm{P}=0.03)$, use eggs $<1$ times per week ( 16.1 vs. $6.0, \mathrm{P}=0.01)$, and use stuck-pot $<1$ times per week $(61.6 \%$ vs. $43.9 \%, \mathrm{P}=0.01)$ (Tables $2,3,4)$.

In the multivariable model, earning higher income was associated with a decreased likelihood of bladder cancer $(\mathrm{AOR}=0.4195 \%, \mathrm{CI}=0.18,0.92)$, while opium consumption and cigarette smoking were associated with an increased chance of bladder cancer. Compared to those who had never used opium, the use of opium up to
Table 2. Cigarette Smoking, Opium and Alcohol Status of 100 Cases with Bladder Cancer and 200 HospitalBased Controls, in Kerman Province in 2020

\begin{tabular}{|c|c|c|c|}
\hline Variables & $\begin{array}{c}\text { Case } \\
(\mathrm{n}=100) \\
\mathrm{N}(\%)\end{array}$ & $\begin{array}{c}\text { Control } \\
(\mathrm{n}=200) \\
\mathrm{N}(\%)\end{array}$ & p-value \\
\hline \multicolumn{3}{|l|}{ Cigarette smoking status } & $\mathrm{p}<0.001$ \\
\hline Never & $28(28.3)$ & $166(83)$ & \\
\hline light smoker & $19(19.2)$ & $24(12)$ & \\
\hline heavy smoker & $52(52.5)$ & $10(5)$ & \\
\hline \multicolumn{3}{|l|}{ Opium consumption } & $\mathrm{p}<0.001$ \\
\hline Never & $25(25.2)$ & $171(85.5)$ & \\
\hline$<18000$ Gram- year & $19(19.2)$ & $14(7)$ & \\
\hline$\geq 18000$ Gram- year & $55(55.6)$ & $15(7.5)$ & \\
\hline \multicolumn{3}{|l|}{ Alcohol use } & 0.02 \\
\hline Never & $90(91.8)$ & $196(98)$ & \\
\hline Ever used & $8(8.2)$ & $4(2)$ & \\
\hline \multicolumn{3}{|c|}{ Age of first cigarette smoke } & 0.82 \\
\hline$<20$ & $16(22.5)$ & $7(20.6)$ & \\
\hline$\geq 20$ & $55(77.5)$ & $27(79.4)$ & \\
\hline \multicolumn{3}{|l|}{ Age of first opium use } & 0.83 \\
\hline$<25$ & $20(27)$ & $7(25)$ & \\
\hline$\geq 25$ & $54(73)$ & $21(75)$ & \\
\hline \multicolumn{3}{|c|}{ second hand exposure to smoking } & 0.02 \\
\hline No & $59(59.6)$ & $146(73)$ & \\
\hline Yes & $40(40.4)$ & $54(27)$ & \\
\hline \multicolumn{3}{|c|}{ Second hand exposure to opium } & 0.24 \\
\hline No & $71(72.5)$ & $156(78.8)$ & \\
\hline Yes & $27(27.6)$ & $42(21.2)$ & \\
\hline \multicolumn{3}{|l|}{ Ever used of hookah } & 0.83 \\
\hline No & $96(97)$ & $193(96.5)$ & \\
\hline Yes & $3(3)$ & $7(3.5)$ & \\
\hline \multicolumn{3}{|c|}{ Ever use of opium derivatives } & 0.33 \\
\hline No & $96(97)$ & $198(99)$ & \\
\hline Yes & $3(3)$ & $2(1)$ & \\
\hline
\end{tabular}

18,000 gram-years in their lifetime was associated with an increased chance of bladder cancer $(\mathrm{AOR}=6 ; 95 \% \mathrm{CI}=$ $2.3,15.5)$. The chance was even higher among those who used opium more than 18000 gram-years in their lifetime $(\mathrm{AOR}=11.3 ; 95 \% \mathrm{CI}=2.3,15.5)$. In comparison with those who had never smoked, the chances of developing bladder cancer increased among those who had smoked up to 20 pack-years of cigarette) $(\mathrm{AOR}=3.4 ; 95 \%, \mathrm{CI}=$ $1.3,8.9)$ and those who smoked $\geq 20$ pack-years $(\mathrm{AOR}=$ $15.8 ; 95 \% \mathrm{CI}=5.9,42.4$ ) (Table 4$)$.

\section{Discussion}

We showed that cigarette smoking, opium consumption, and low level of income ( $<20$ million Rials) independently increase the chance of bladder cancer. No relationship was found between diet, alcohol consumption, second-hand cigarette smoke, opium use, job, and the likelihood of bladder cancer. 
Table 3. Occupational, environmental and Diet Status of 100 Cases with Bladder Cancer and 200 Hospital-Based Controls, in Kerman Province in 2020

\begin{tabular}{|c|c|c|c|}
\hline Variables & $\begin{array}{c}\text { Case } \\
(\mathrm{n}=100) \\
\mathrm{N}(\%)\end{array}$ & $\begin{array}{c}\text { Control } \\
(n=200) \\
N(\%)\end{array}$ & $\mathrm{p}$-value \\
\hline \multicolumn{3}{|c|}{ History of work in industrial factories } & 0.03 \\
\hline No & $86(89.9)$ & $192(96)$ & \\
\hline Yes & $10(10.1)$ & $8(4)$ & \\
\hline \multicolumn{3}{|c|}{ Residing in proximity to industrial zone } & 0.03 \\
\hline$<2 \mathrm{~km}$ & $81(81.8)$ & $182(91)$ & \\
\hline$\geq 2 \mathrm{~km}$ & $18(18.2)$ & $18(9)$ & \\
\hline \multicolumn{3}{|c|}{ Exposure to chemical fertilizers } & 0.01 \\
\hline No & $58(58.6)$ & $145(72.5)$ & \\
\hline Yes & $41(41.4)$ & $55(27.5)$ & \\
\hline \multicolumn{3}{|c|}{ Ever working as a driver } & $\mathrm{p}<0.001$ \\
\hline No & $76(76.8)$ & $186(93)$ & \\
\hline Yes & $23(23.2)$ & $14(7)$ & \\
\hline \multicolumn{3}{|c|}{ Ever working as a farmer } & 0.03 \\
\hline No & $43(43.4)$ & $113(56.5)$ & \\
\hline Yes & $56(56.6)$ & $87(43.5)$ & \\
\hline \multicolumn{3}{|c|}{ Ever working as construction worker } & 0.001 \\
\hline No & $77(77.8)$ & $184(92)$ & \\
\hline Yes & $22(22.2)$ & $16(8)$ & \\
\hline \multicolumn{3}{|l|}{ Use of grilled foods } & 0.02 \\
\hline$<1$ time per week & $58(58.6)$ & $86(43.4)$ & \\
\hline 1-3 times per week & $35(35.4)$ & $102(51.5)$ & \\
\hline$\geq 4$ times per week & $6(6.6)$ & $10(5.1)$ & \\
\hline \multicolumn{3}{|l|}{ Stuck-pot } & 0.01 \\
\hline$<1$ time per week & $61(61.6)$ & $87(43.9)$ & \\
\hline 1-3 times per week & $32(32.3)$ & $93(47)$ & \\
\hline$\geq 4$ times per week & $6(6.1)$ & $18(9.1)$ & \\
\hline \multicolumn{3}{|c|}{ carbonated drink and juices with preservatives } & 0.03 \\
\hline$<1$ time per week & $20(20.2)$ & $63(31.8)$ & \\
\hline 1-3 times per week & $32(32.3)$ & $69(34.9)$ & \\
\hline$\geq 4$ times per week & $47(47.5)$ & $66(33.3)$ & \\
\hline \multicolumn{3}{|l|}{ Use of egg } & 0.01 \\
\hline$<1$ time per week & $16(16.1)$ & $12(6)$ & \\
\hline 1-3 times per week & $60(60.6)$ & $135(67.8)$ & \\
\hline$\geq 4$ times per week & $23(23.2)$ & $52(26.1)$ & \\
\hline \multicolumn{3}{|l|}{ Cereals } & 0.13 \\
\hline 1-3 times per week & $7(7.1)$ & $6(3)$ & \\
\hline$\geq 4$ times per week & $92(92.9)$ & $193(97)$ & \\
\hline \multicolumn{3}{|l|}{ Pickle } & 0.08 \\
\hline$<1$ time per week & $64(64.7)$ & $103(52)$ & \\
\hline 1-3 times per week & $28(28.3)$ & $69(34.9)$ & \\
\hline$\geq 4$ times per week & $7(7.1)$ & $26(13.1)$ & \\
\hline
\end{tabular}

We observed a strong dose-response relationship between the amount of opium consumption in gram-years and bladder cancer. The chance of bladder cancer increased 6 times among cases who used up to 18,000 gram-years in their lifetime. However, consumption of 18,000 gram-years opium and more increased the chance of bladder cancer by 11.3 times. The results of a systematic review and meta-analysis conducted in 2021 show a 3.8 times increase in chances of developing bladder cancer among opium users (Bidary et al., 2021), which is lower than our estimates. This may be due to differences in population selection, exposure definition and measurement, confounding factor control, and adjustments between individual studies included in this meta-analysis. Opium has been found to affect cancer through several mechanisms. A study conducted by Etemadi et al., (2020) showed that the concentration of polycyclic aromatic hydrocarbons (PAH), and volatile organic compounds (VOC) among exclusive opium users is higher than it is in non-users. Exposure to these chemicals has been associated with bladder cancer. Furthermore, Malaveille et al., (1982) demonstrated that pyrolysis of opium and its alkaloids may produce mutagens and possibly increase the risk of bladder cancer. Also, opium has displayed mutagenic activity in animal experiments, and sister chromatid exchanges have been observed in human peripheral blood lymphocytes (Perry et al., 1983). Increasing the methylation of DNA through the reduction of $\mathrm{N}$-nitrosamines and $\mathrm{N}$-nitrosodimethylamine through liver clearance was has been observed in association with morphine, one of the opium alkaloids (Hosseini et al., 2010; Karbakhsh et al., 2013). Urinary retention and consequently prolonged exposure of bladder with carcinogenic chemicals may increase the chance of bladder cancer, and opium impurities, such as lead and arsenic, may play a role in the carcinogenicity of opium (Schiff, 2002; Aghababaei et al., 2018).

Similarly, we observed a dose-response pattern between the amount of lifetime cigarette smoking and bladder cancer. In our study, light smoking and heavy smoking were associated with a 3-time and a 15-time increased chance of bladder cancer, respectively. The higher risk of bladder cancer among cigarette smokers has been addressed in previous studies (Rink et al., 2015; Masaoka et al., 2016). At least 70 carcinogenic compounds such as aromatic amines and N-nitroso are known to exist in cigarettes. Cigarette-gene interactions involve DNA damage in the form of genomic events such as double-stranded breaks, base modifications, and bulky adduct formation (Stern et al., 2009; Jin et al., 2017). In line with previous studies (Lotfi et al., 2016; Weiner et al., 2018), we observed a reverse association between the level of income and bladder cancer, with higher income associated with a decreased likelihood of bladder cancer. High income may protect people against disease through greater access to medical services, better nutrition, and higher levels of awareness.

In contrast to some previous studies, we saw no association between occupation and bladder cancer. In a review conducted in 2020, the chances of developing bladder cancer were estimated to be 11.3 times greater than the general population; the study estimated that bus and heavy vehicle drivers, farmers, fishers, foresters, metalworkers, and welders were 6 times more likely 
DOI:10.31557/APJCP.2021.22.10.3385

Opium and Cigarette Smoking Effect on Bladder Cancer

Table 4. Distribution of 100 Cases with Bladder Cancer and 200 Hospital-Based Controls, ORs, and Corresponding 95 \% CIs by Association Factors in Kerman Province in 2020

\begin{tabular}{|c|c|c|c|c|c|c|}
\hline Variables & $\begin{array}{c}\text { Case } \\
(\mathrm{n}=100) \\
\mathrm{N}(\%)\end{array}$ & $\begin{array}{c}\text { Control } \\
(n=200) \\
N(\%)\end{array}$ & $\begin{array}{l}\text { Crude OR } \\
(95 \% \mathrm{CI})\end{array}$ & p-value & $\begin{array}{c}\text { Adjusted OR } \\
(95 \% \mathrm{CI})\end{array}$ & p-value \\
\hline \multicolumn{4}{|l|}{ Income } & 0.001 & & 0.032 \\
\hline$<20$ million Rials & $80(80.8)$ & $125(62.5)$ & Referent & \multicolumn{3}{|c|}{ Referent } \\
\hline$\geq 20$ million Rials & $19(19.2)$ & $75(37.5)$ & $0.39(0.22-0.70)$ & \multicolumn{3}{|c|}{$0.41(0.18-0.92)$} \\
\hline \multicolumn{4}{|l|}{ Education (year) } & \multirow{3}{*}{\multicolumn{2}{|c|}{0.01}} & \multirow[t]{3}{*}{-} \\
\hline$<12$ & $82(82.8)$ & $140(70)$ & Referent & & & \\
\hline$\geq 12$ & $17(17.2)$ & $60(30)$ & 0.48 & & & \\
\hline \multicolumn{7}{|l|}{ Cigarette smoking } \\
\hline Never & $28(28.3)$ & $166(83)$ & Referent & \multicolumn{3}{|c|}{ Referent } \\
\hline light smoker & $19(19.2)$ & $24(12)$ & $4.69(2.3-9.7)$ & $\mathrm{p}<0.001$ & $3.4(1.3-8.9)$ & 0.014 \\
\hline heavy smoker & $52(52.5)$ & $10(5)$ & $30.82(14.04-67.7)$ & $\mathrm{p}<0.001$ & $15.8(5.9-42.4)$ & $\mathrm{p}<0.001$ \\
\hline \multicolumn{7}{|l|}{ Opium consumption } \\
\hline Never & $25(25.2)$ & $171(85.5)$ & Referent & \multicolumn{3}{|c|}{ Referent } \\
\hline$<18000$ Gram - year in life time & $19(19.2)$ & $14(7)$ & $10.3(4.8-22)$ & $\mathrm{p}<0.001$ & $6(2.3-15.5)$ & $\mathrm{p}<0.001$ \\
\hline$\geq 18000$ Gram - year in life time & $55(55.6)$ & $15(7.5)$ & $26.3(12.5-55.2)$ & $\mathrm{p}<0.001$ & $11.3(2.3-15.5)$ & $\mathrm{p}<0.001$ \\
\hline \multicolumn{4}{|l|}{ Alcohol use } & 0.019 & \multirow[t]{3}{*}{-} & \multirow[t]{3}{*}{-} \\
\hline Never & $90(91.8)$ & $196(98)$ & Referent & & & \\
\hline Ever use & $8(8.2)$ & $4(2)$ & $4.4(1.3-14.8)$ & & & \\
\hline \multicolumn{4}{|l|}{ Second hand exposure to smoking } & 0.02 & \multirow[t]{3}{*}{ - } & \multirow[t]{3}{*}{-} \\
\hline No & $59(59.6)$ & $146(73)$ & Referent & & & \\
\hline Yes & $40(40.4)$ & $54(27)$ & $1.8(1.1-3)$ & & & \\
\hline \multicolumn{4}{|l|}{ Second hand exposure to opium } & 0.22 & \multirow[t]{3}{*}{ - } & \multirow[t]{3}{*}{-} \\
\hline No & $71(72.5)$ & $156(78.8)$ & Referent & & & \\
\hline Yes & $27(27.6)$ & $42(21.2)$ & $1.4(0.8-2.5)$ & & & \\
\hline \multicolumn{4}{|l|}{ History of work in industrial factories } & 0.04 & \multirow[t]{3}{*}{-} & \multirow[t]{3}{*}{-} \\
\hline No & $86(89.9)$ & $192(96)$ & Referent & & & \\
\hline Yes & $10(10.1)$ & $8(4)$ & $2.7(1-7.1)$ & & & \\
\hline \multicolumn{4}{|c|}{ Residing in proximity to industrial zone } & 0.02 & - & - \\
\hline$<2 \mathrm{~km}$ & $81(81.8)$ & $182(91)$ & Referent & & & \\
\hline$\geq 2 \mathrm{~km}$ & $18(18.2)$ & $18(9)$ & $2.4(1.1-4.5)$ & & & \\
\hline Exposure to chemical fertilizers & & & & 0.01 & _ & _ \\
\hline No & $58(58.6)$ & $145(72.5)$ & Referent & & & \\
\hline Yes & $41(41.4)$ & $55(27.5)$ & $1.9(1.1-3.1)$ & & & \\
\hline Ever working as a driver & & & & $\mathrm{p}<0.001$ & - & - \\
\hline No & $76(76.8)$ & $186(93)$ & Referent & & & \\
\hline Yes & $23(23.2)$ & $14(7)$ & $4(2-8.2)$ & & & \\
\hline Ever working as a farmer & & & & 0.03 & - & - \\
\hline No & $43(43.4)$ & $113(56.5)$ & Referent & & & \\
\hline Yes & $56(56.6)$ & $87(43.5)$ & $1.7(1-2.7)$ & & & \\
\hline Ever working as a construction wor & & & & 0.001 & - & - \\
\hline No & $77(77.8)$ & $184(92)$ & Referent & & & \\
\hline Yes & $22(22.2)$ & $16(8)$ & $3.3(1.6-6.6)$ & & & \\
\hline Use of grilled foods & & & & & - & - \\
\hline$<1$ time per week & $58(58.6)$ & $86(43.4)$ & Referent & & & \\
\hline 1-3 time per week & $35(35.4)$ & $102(51.5)$ & $0.5(0.3-0.8)$ & 0.009 & & \\
\hline$\geq 4$ times per week & $6(6.6)$ & $10(5.1)$ & $0.9(0.3-2.6)$ & 0.83 & & \\
\hline
\end{tabular}


Table 4. Continued

\begin{tabular}{|c|c|c|c|c|c|c|}
\hline Variables & $\begin{array}{c}\text { Case } \\
(\mathrm{n}=100) \\
\mathrm{N}(\%)\end{array}$ & $\begin{array}{c}\text { Control } \\
(n=200) \\
N(\%)\end{array}$ & $\begin{array}{l}\text { Crude OR } \\
(95 \% \mathrm{CI})\end{array}$ & p-value & $\begin{array}{c}\text { Adjusted OR } \\
(95 \% \mathrm{CI})\end{array}$ & p-value \\
\hline Stuck-pot & & & & & - & - \\
\hline$<1$ time per week & $61(61.6)$ & $87(43.9)$ & Referent & & & \\
\hline 1-3 time per week & $32(32.3)$ & $93(47 \%)$ & $0.5(0.3-0.8)$ & 0.007 & & \\
\hline$\geq 4$ times per week & $6(6.1)$ & $18(9.1)$ & $0.5(0.2-1.3)$ & 0.13 & & \\
\hline \multicolumn{5}{|c|}{ carbonated drink and juices with preservatives } & \multirow{4}{*}{-} & \multirow{4}{*}{-} \\
\hline$<1$ time per week & $20(20.2)$ & $63(31.8)$ & Referent & & & \\
\hline 1-3 time per week & $32(32.3)$ & $69(34.9)$ & $1.5(0.8-2.8)$ & 0.25 & & \\
\hline$\geq 4$ times per week & $47(47.5)$ & $66(33.3)$ & $2.2(1.2-4.2)$ & 0.01 & & \\
\hline \multicolumn{5}{|l|}{ Use of egg } & \multirow[t]{4}{*}{ - } & \multirow[t]{4}{*}{-} \\
\hline$<1$ time per week & $16(16.1)$ & $12(6 \%)$ & Referent & & & \\
\hline 1-3 time per week & $60(60.6)$ & $135(67.8)$ & $0.3(0.1-0.7)$ & 0.008 & & \\
\hline$\geq 4$ times per week & $23(23.2)$ & $52(26.1)$ & $0.3(0.1-0.8)$ & 0.016 & & \\
\hline \multicolumn{4}{|l|}{ Cereals } & 0.11 & \multirow[t]{3}{*}{ - } & \multirow[t]{3}{*}{ - } \\
\hline 1-3 time per week & $7(7.1)$ & $6(3.1)$ & Referent & & & \\
\hline$\geq 4$ times per week & $92(92.9)$ & $193(97)$ & $0.4(0.1-1.3)$ & & & \\
\hline \multicolumn{5}{|l|}{ Pickle } & \multirow[t]{4}{*}{ - } & \multirow[t]{4}{*}{ - } \\
\hline$<1$ time per week & $64(64.7)$ & $103(52.1)$ & Referent & & & \\
\hline 1-3 time per week & $28(28.3)$ & $69(34.9)$ & $0.7(0.4-1.1)$ & 0.12 & & \\
\hline$\geq 4$ times per week & $7(7.1)$ & $26(13.1)$ & $0.4(0.2-1.1)$ & 0.06 & & \\
\hline
\end{tabular}

to develop bladder cancer (Farmanfarma et al., 2020). Our bivariate analysis showed that working in industrial factories, residing in proximity to factories, exposure to chemical fertilizers, and working as drivers, as farmers, or as construction workers were associated with bladder cancer, but the findings didn't last in multivariableadjusted analysis. This finding suggests that the observed association between occupation and bladder cancer in previous studies may be explained by the confounding role of opium and cigarettes. The findings of an ecologic study on 160 countries demonstrated an association between opiate use and bladder cancer (Rashidian et al., 2016). Based on the national population size estimation of drug users in Iran in 2013, Kerman ranked fifth in terms of opium consumption and ranked third in terms of shire (combination of opium residue and pure opium) consumption (Nikfarjam et al., 2016). The high prevalence of opium use in Kerman province may explain the higher incidence of bladder cancer seen in the population-based cancer registry data (Shahesmaeili et al., 2018).

The present study's findings provided important insights into the risk factors of bladder cancer, the most common cancer among men in Kerman province. In contrast to previous studies, we tried to measure all possible risk factors of bladder cancer and adjust the results to minimize any confounding effect based on a comprehensive literature review. Precise measurement of opium consumption and cigarette smoking is strength of the present study. However, as in all case-control studies, bias in the recall of past exposures may be an issue.

The strong dose-response association between opium consumption, cigarette smoking, and bladder cancer highlights the need for extension of prevention and harm reduction programs, especially in regions with a high burden of disease. As opium users and cigarette smokers are at higher risk of bladder cancer, it is recommended that the cost-effectiveness of early screening and early detection policies.

\section{Author Contribution Statement}

$\mathrm{ASH}$ and $\mathrm{AB}$ conceptualized the study. ASH, ZA, HP, MSH, HP designed the methodology and study instruments. ZAAND MM performed the data processing and analysis. ASH and ZA drafted the manuscript. All authors reviewed and edited the final manuscript and approved the submitted version.

\section{Acknowledgements}

\section{Funding statement}

This study was funded by Kerman University of Medical Sciences, Kerman, Iran. The present article extracted from MSc thesis of Z.A

\section{Ethical approval}

The study protocol was reviewed and approved by the Research Review Board of the Kerman University of Medical Sciences (ethics code: IR.KMU.REC.1398.603).

\section{Availability of data}

The datasets used and/or analyzed during the current study are available from the corresponding author on reasonable request. 
Conflict of interest

All the authors declare no conflict of interest.

\section{References}

Aghababaei R, Javadi I, Nili-Ahmadabadi A, et al (2018). Occurrence of bacterial and toxic metals contamination in illegal opioid-like drugs in Iran: a significant health challenge in drug abusers. DARU J Pharm Sci, 26, 77-83.

Ahmadi M, Ranjbaran H, Amiri MM, et al (2012). Epidemiologic and socioeconomic status of bladder cancer in Mazandaran Province, northern Iran. Asian Pac J Cancer Prev, 13, 5053-6.

Bidary MZ, Sahranavard M, Rezayat AA, et al (2021). Opium as a carcinogen: A systematic review and meta-analysis. E Clin Med, 33, 100768.

Bravi F, Spei M-E, Polesel J, et al (2018). Mediterranean diet and bladder cancer risk in Italy. Nutrients, 10, 1061.

Etemadi A, Poustchi H, Calafat AM, et al (2020). Opiate and tobacco use and exposure to carcinogens and toxicants in the Golestan Cohort Study. Cancer Epidemiol Prev Biomarkers, 29, 650-8.

Farmanfarma KK, Mahdavifar N, Salehiniya H (2020). Bladder Cancer in Iran: An Epidemiological Review. Res Rep Urol, 12,91 .

Hassanipour S, Delam H, Fathalipour M, et al (2019). The incidence of bladder cancer in Iran: a systematic review and meta-analysis. World Cancer Res J, 6, 1-10.

Hosseini SY, Safarinejad MR, Amini E, et al Opium consumption and risk of bladder cancer: a case-control analysis. Urol Oncol Semin Original Invest, 2010. Elsevier, 610-6.

Jin F, Thaiparambil J, Donepudi SR, et al (2017). Tobacco-specific carcinogens induce hypermethylation, DNA adducts, and DNA damage in bladder cancer. Cancer Prev Res, 10, 588-97.

Karbakhsh M, Dabbagh N, Shabani A, et al (2013). Age at diagnosis in bladder cancer: does opium addiction play a role?. Asian Pac J Cancer Prev, 14, 4723-5.

Khazaei Z, Mosavi Jarrahi A, Momenabadi V, et al (2019). Global cancer statistics 2018: GLOBOCAN estimates of incidence and mortality worldwide stomach cancers and their relationship with the human development index (HDI). World Cancer Res J, 6, e1257.

Koutros S, Silverman DT, Alavanja MC, et al (2016). Occupational exposure to pesticides and bladder cancer risk. Int J Epidemiol, 45, 792-805.

Lotfi MH, Farzaneh F, Mehrparvar AH, et al (2016). The effect of smoking and opium on bladder cancer in yazd province: A Case-Control Study. J Commun Health Res, 5, 98-109.

Malakootian M, Mohammadi Senjedkooh S (2014). Quality Assessment of SIRJAN plain groundwater resources to Evaluate Their Contamination to Heavy Metals at 2014. $J$ Torbat Heydariyeh Univ Med Sci, 2, 31-9.

Malaveille C, Friesen M, Camus A-M, et al (1982). Mutagens produced by the pyrolysis of opium and its alkaloids as possible risk factors in cancer of the bladder and oesophagus. Carcinogenesis, 3, 577-85.

Masaoka H, Matsuo K, Ito H, et al (2016). Cigarette smoking and bladder cancer risk: an evaluation based on a systematic review of epidemiologic evidence in the Japanese population. Jpn J Clin Oncol, 46, 273-83.

Miller KD, Goding Sauer A, Ortiz AP, et al (2018). Cancer statistics for hispanics/latinos, 2018. CA Cancer J Clin, 68, 425-45.

Najafipour H, Masoomi M, Shahesmaeili A, et al (2015). Effects of opium consumption on coronary artery disease risk factors and oral health: Results of Kerman Coronary Artery Disease
Opium and Cigarette Smoking Effect on Bladder Cancer

Risk factors Study a population-based survey on 5900 subjects aged 15-75 years. Int J Prev Med, 6.

Nazari Y, Abbasnejad A (2015). Determining the Origin and Distribution of Arsenic in Groundwater in the Rayen Plain (Southeast of Kerman) using Statistical Techniques.

Nikfarjam A, Shokoohi M, Shahesmaeili A, et al (2016). National population size estimation of illicit drug users through the network scale-up method in 2013 in Iran. Int J Drug Policy, 31, 147-52.

Perry P, Thomson E, Day N, et al (1983). Induction of SCE by opium pyrolysates in $\mathrm{CHO}$ cells and human peripheral blood lymphocytes. Carcinogenesis, 4, 227-30.

Rashidian H, Zendehdel K, Kamangar F, et al (2016). An ecological study of the association between opiate use and incidence of cancers. Addiction Health, 8, 252.

Rink M, Crivelli JJ, Shariat SF, et al (2015). Smoking and bladder cancer: a systematic review of risk and outcomes. Eur Urol Focus, 1, 17-27.

Schiff PL (2002). Opium and its alkaloids. Am J Pharm Edu, 66, 188-96.

Shahesmaeili A, Afshar RM, Sadeghi A, et al (2018). Cancer incidence in Kerman Province, Southeast of Iran: report of an ongoing population-based cancer registry, 2014. Asian Pac J Cancer Prev, 19, 1533.

Stern MC, Lin J, Figueroa JD, et al (2009). Polymorphisms in DNA repair genes, smoking, and bladder cancer risk: findings from the international consortium of bladder cancer. Cancer Res, 69, 6857-64.

Weiner AB, Keeter M-K, Manjunath A, et al Discrepancies in staging, treatment, and delays to treatment may explain disparities in bladder cancer outcomes: an update from the National Cancer Data Base (2004-2013). Urol Oncol Semin Original Invest, 237, 9-17.

Wong MC, Fung FD, Leung C, et al (2018). The global epidemiology of bladder cancer: a joinpoint regression analysis of its incidence and mortality trends and projection. Sci Rep, 8, 1-12.

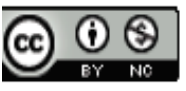

This work is licensed under a Creative Commons AttributionNon Commercial 4.0 International License. 